\title{
Land Politics and Local State Capacities: The Political Economy of Urban Change in China
}

\section{Citation}

Rithmire, Meg. "Land Politics and Local State Capacities: The Political Economy of Urban

Change in China." China Quarterly, no. 216 (December 2013): 1-24.

\section{Published Version}

doi:10.1017/S0305741013001033

\section{Permanent link}

http://nrs.harvard.edu/urn-3:HUL.InstRepos:11508224

\section{Terms of Use}

This article was downloaded from Harvard University's DASH repository, and is made available under the terms and conditions applicable to Open Access Policy Articles, as set forth at http:// nrs.harvard.edu/urn-3:HUL.InstRepos:dash.current.terms-of-use\#OAP

\section{Share Your Story}

The Harvard community has made this article openly available.

Please share how this access benefits you. Submit a story.

\section{Accessibility}




\title{
Land Politics and Local State Capacities: The Political Economy of Urban Change in China $^{1}$
}

\begin{abstract}
:
Despite common national institutions and incentives to remake urban landscapes to anchor growth, generate land-lease revenues, and display a capacious administration, Chinese urban governments exhibit varying levels of control over land. This article uses a paired comparison of Dalian and Harbin in China's Northeast to link differences in local political economies to land politics. Dalian, benefitting from early access to foreign capital, consolidated control over urban territory through the designation of a development zone, which realigned local economic interests and introduced dual pressures for enterprises to restructure and relocate. Harbin, facing capital shortages, distributed urban territory to assuage losers of reform and promote economic growth. The findings suggest that 1) growth strategies, and the territorial politics they produce, are products the post-Mao urban hierarchy rather than of socialist legacies, and,2) perhaps surprisingly, local governments exercise the greatest control over urban land in cities that adopted market reforms earliest.
\end{abstract}

The international community has looked on the phenomenal process of urbanization and urban spatial restructuring in China with equal parts awe and suspicion. While some interpret Chinese advances in infrastructure as evidence of the country's coming of age, others emphasize the "dominance of the state" at the expense of individuals and major groups in society. ${ }^{2}$ The pace and scale of urban growth, infrastructure construction and spatial restructuring has become, in the aggregate, a metaphor for China's economic miracle. For individual cities, urban landscapes serve as manifestations of ambition and evidence of a promising future. Nearly every Chinese city has a museum devoted to urban planning, typically showcasing the city's spatial and territorial ambitions in the next ten to thirty years. Reading the urban strategic plans for any size Chinese city can be an exercise in repetition: nearly every one aspires to be a "global hub," a "cultural, economic, and political center," and an attractive environment for foreign and domestic investment. The similarity of these ambitions, however, belies deep divergence in growth strategies and changes to urban landscapes. Presumably, all local governments want to 
remake the urban landscape to be better suited to both anchoring economic investment and displaying a modern and capacious administration. Yet, some cities boast successful implementation of projects to relocate enterprises and residents, establish special function economic zones, and landscapes generally free of illegal construction and slums, whereas other cities have poor records of implementing their own urban planning projects and landscapes that reflect such a lack of control.

This article draws on a paired comparison of two similar cities in a single region- the Northeastern rust belt — to argue that patterns of urban land politics are products of the different political economies created by changes in the post-Mao urban hierarchy and the sequencing of opening and reform. Dalian in Liaoning Province, like many cities that benefitted from early access to foreign capital as a result of preferential policies bestowed by Beijing, designated a development zone outside the urban core to rebalance the concentration of economic power in favor of pro-reform coalitions while leaving the urban core, the pre-reform power base, undisturbed during the early states of reform and opening. The city of Harbin, which did not enjoy open privileges until the mid-1990s, instead pursued decentralization of authority over policies such as housing, enterprise reform, and the growth of private entrepreneurship, distributing urban land control to assuage losers of economic reforms and spur growth. The different reform era urban political economies - resulting from changes to the urban hierarchy and the distribution of preferential policies from Beijing - have produced different approaches to urban territory and patterns of land control in these initially similar cities.

\section{MUNICIPAL STATES AND URBAN POLITICS IN CHINA}


Territory - politicized space over which groups struggle for control, occupation, and access - is an important locus of political conflict in China. ${ }^{3}$ Urban land may simply be a commodity, but territorial politics emerge when various factions struggle for political control of land. Confrontation between citizens and local authorities over land has been one of the most visible flashpoints of state-society conflict in rural and urban China alike. In rural areas, the requisition of collectively-owned (jiti 集体) farmland has constituted an incendiary process of conflict between peasants and local governments. ${ }^{4}$ In urban China, both the international media and scholars have turned their attention toward grand projects of urban renewal and transformation and the dislocations and historical destruction that accompany them. ${ }^{5}$ Moreover, the combination of local government reliance on land-leasing for revenues and real estate speculation has driven up housing and property values across urban China, constituting a potential social crisis as many are squeezed out of the housing market and a potential economic crisis in the form of an asset bubble. ${ }^{6}$

You-Tien Hsing has characterized the urban politics of the 1990s in China as “competition for urban land control." Hsing envisions municipal state agents pitted against collective and state-owned factory managers and other quasi-state actors who have de facto rights to urban land based on long-term usage, in a struggle for control of land resources within the urban core: "China's urban politics unfolds as an intra-state struggle over land by these two sets of statist actors. ${ }^{, 7}$ However, not all cities appear mired in the kind of intra-state conflict that she emphasizes. Moreover, participants outside of the state—urban residents, private economic actors, informal sector workers who occupy dilapidated or unmanaged spaces, and so forthmay mount significant challenges to the local state's pursuit of territorial control. Why are some local governments successful in outmaneuvering competitors for land control when others are 
not, and under what conditions do other urban groups exercise meaningful control over the urban landscape? To this end, we may understand variation in the local state's ability to monopolize the allocation of urban property rights territorial consolidation and territorial fragmentation. A local state has consolidated its control over the territory within its purview when it is the sole arbiter of the rights to the use, transfer, and income generated from urban land. Territorial fragmentation characterizes cities in which multiple and competing claims to urban land, from groups both in and outside of the state, thwart the municipal state's efforts at spatial restructuring. This article expands on Hsing's formulation to address this inter-urban variation. More specifically, I propose a comparative political economy of land politics that links differences in economic development strategies to patterns of urban territorial control. ${ }^{8}$

What follows details how different political economies of growth and reform took shape in initially similar cities as they sought to pursue growth given different resources and constraints. While much has been made of decentralization and urban China as a "laboratory for reform," the distribution and timing of preferential policies from Beijing allowed some cities access to foreign capital before or as they undertook politically difficult reforms, while others undertook reforms under resource constraints. These changes to the post-Mao urban hierarchy have created fundamentally different rules of state-market relations across urban China, in evidence in this article with regard to growth and territorial strategies. In both cities, the management of land was integral to growth and reform strategies, but according to different logics. Dalian neglected the traditional urban core to build a new base of economic vitality and political support in the development zone, then later simultaneously recapitalized on downtown land while implementing enterprise reforms. Harbin, facing capital shortages, treated urban territory as a resource for distribution to real and potential losers of reform, steadily relinquishing 
control to residents, enterprises, and even lower levels of the municipal government. The management of intra-local competition established patterns of territoriality that continue to mark urban landscapes and structure urban politics today.

Some clarification about methods, sources, and definitions is in order before proceeding. First, I analyze the relationship between land politics and political economy at the municipal as opposed to the provincial level for two primary reasons. First, because financial revenues generated through land development (in the form of both taxes and land-lease fees) accrue to local governments, decisions about specific sites of urban redevelopment and expansion are generally initiated and implemented at the local level. Second, preferential policies that determine the sequencing and extent of reform and opening are also bestowed on cities rather than provinces. Given that the opening of land-leasing markets was national policy in the late 1980s and early 1990s and a lack of variation in provincial level policies toward land and housing, the comparison of cities is most appropriate. ${ }^{9}$ That Harbin is a provincial capital and Dalian is not may complicate the comparison, as some scholars have suggested that power in provincial capitals leans heavily toward the state and away from social actors, and therefore that they should be analyzed in a category unto themselves. ${ }^{10}$ In this comparison, however, the provincial capital proves to be the lesser capacious in managing land politics, so if anything the the relevance of political economy and the sequencing of reforms seems robust to differences in administrative hierarchy in this case. In considering urban politics in China, however, the boundaries of the "municipality" is all but clear, since cities encompass urban districts as well as counties and sub-urban cities. ${ }^{11}$ In this article, I discuss land politics in the urban districts (shiqu 市区) only in Harbin and Dalian, therefore excluding the counties and subsidiary cities under the administrative purview of these municipalities. In both cities, expansion in the form of 
development zones and “new cities" (xinqu, 新区) has brought the conversion of counties into urban districts (i.e. Dalian's Jinzhou County became Jinzhou District in 1987, and Hulan County split into Hulan and Songbei urban districts in Harbin in 2004 with the development of the Jiangbei New Area). I refer to the urban districts existing at the beginning of the reform era as the "urban core," as opposed to new districts and development zones established during urban expansion since the early 1980s. See Figures 2 and 3 for maps of each city.

This article relies on data gathered during twelve months of fieldwork between in 2007 and 2008. Sources include written materials gathered from local libraries, the Harbin Municipal Archives, and materials on urban planning and land policies kindly shared by local officials and researchers and on file with the author. My observations also rely on formal but unstructured interviews conducted with roughly two sets of local actors: first, urban planners and academics, groups that more frequently than not overlap in Chinese cities. The second group consisted of local government economic officials, chiefly from Municipal Land Resource Bureaux, Municipal Bureaux of Industry and Commerce, and local branches of the Development and Reform Commission. Ever subject to the limits of access when conducting research on topics as politically sensitive as land conflict in urban China, the scope of interviewees is less comprehensive and the data relayed in them subject to greater scrutiny. However, I purposefully combine impressionistic data relayed in interviews with a heavy reliance on written sources and documentation to create as reliable a narrative as possible of urban change within these two cities.

\section{TWO CITIES, ONE REGION: DALIAN AND HARBIN}

(Figure 1 here) 
Northeastern China, China's “Old Industrial Base,” provides an ideal laboratory in which to investigate the phenomena of post-socialist urban reform and territoriality. The regionconsisting of Heilongjiang, Liaoning, and Jilin provinces — entered the Maoist era with a strong industrial base established during the construction of the China Eastern Railway and during Japanese occupation. After 1949, the region continued to be home to China's industrial base, as urban areas received large amounts of state investment for the construction of state-owned enterprises focused on heavy industrial production. Cities in the Northeast, then, share a similar set of legacies from the command economy: vast numbers of formal sector workers and the attendant social welfare burdens, local economies dominated by state-owned enterprises, a relative lack of diaspora connections compared to the coastal Southeast, and strong institutions designed for collective production and consumption. ${ }^{12}$

In the reform era, the once-privileged provinces of the Northeast have suffered a "drastic reversal of fortune" as they are home to the greatest "institutional liabilities and legacies of the command economy" and have seen precious little of the dynamism that characterizes regional economies elsewhere. ${ }^{13}$ Yet, the fortunes of reform have favored Dalian and Harbin very differently (see Table 1). Dalian has managed to "reterritorialize" itself out of the rustbelt and into the global economy. ${ }^{14}$ Harbin, on the other hand, is said to have "dropped off the central government's radar screen" after $1979 .{ }^{15}$ These differences in political economy, rooted in the distribution of preferential policies from Beijing, are attended by differences in demonstrated control over the urban landscape.

In the early 1990s, Dalian began to attract the attention and envy of many cities as it amassed prestigious awards and titles related to its achievements in the urban environment: "Environmental Protection Model City" in 1992, one of China's "Ten Most Beautiful" in 1992, 
and the first city in China and second in Asia to be included in the UN "Global 500" for livable environments in 1995. ${ }^{16}$ Dalian's urban landscape evinces a palpable presence of state control and urban management to the visitor, mostly free of informal markets, dilapidated housing, and visible signs of urban blight or poverty, especially in urban core commercial areas and the city's new industrial districts. Dalian officials, as reflected in everything from municipal publications to a museum devoted to showcasing the construction of "Modern Dalian," are extremely proud of the city's appearance. Long-time Dalian mayor Bo Xilai celebrated in an interview that real estate prices in downtown Dalian increased 500\% between 1994 and 1999, a development that

certainly benefitted municipal authorities who leased downtown land to developers. ${ }^{17}$

\section{(Table 1 here)}

The urban landscape in Harbin, on the other hand, confronts the visitor with a visual mélange of the results of the reform era. Harbiners often refer to the three core urban districts of the city, Daoli, Nangang, and Daowai, as “heaven” (tiandi 天地), “purgatory” (lianyu 炼狱), and “hell” or “the inferno” (diyu 地狱), respectively. Daoli District is home to much of the city’s characteristic Russian architecture, the commercial and retail center of the city, and a great deal of new development projects that capitalize on prime real estate prices through high overhead commercial centers or high-rise residential buildings. Many of the city's universities as well as its embryonic Central Business District are located in Nangang District, where main arteries display department stores and modern residential compounds next door to informal street markets, pre-reform housing units, and buildings associated with now closed factories with the character for "demolition" (chai 拆) displayed prominently on every surface. During my tenmonth tenure in the city, many of these areas slated for demolition remained untouched by 
bulldozers and occupied by former residents, even without heat in China's harshest winter. Daowai District, called "the inferno" not only as a reference to hell but also because of the frequency of conflagrations when residents heat wooden homes by fire, typifies post-industrial urban blight: abandoned buildings, haphazard new construction, few signs of disposable income, few large parks and green areas, and so forth. Yet, residents seem in no hurry to flee their neighborhoods for higher ground. Street-level commerce is visibly vibrant, real estate prices (even for quite old structures) are as high as other parts of the city, and relations among neighbors appear mutually dependent. ${ }^{18}$

\section{(Figure 2 here)}

Harbin has mounted two unsuccessful attempts to expand outside the urban core: a new district north of the Songhua River and a "high technology development zone" to the west. These new areas are called, respectively, “Ghostown” (guicheng 鬼城) and “Corruption Street” (fubai de yitiaojie 腐败的一条街). Land for the Songbei new zone was requisitioned in the mid-1990s, but development did not begin until the first few years of the 2000s. ${ }^{19}$ In the district's early period, many wealthy Harbiners purchased apartments in Songbei as investments, but have not been able to rent their properties and have themselves not moved because of transportation inconvenience and the lack of commercial and retail development in the area. ${ }^{20}$ The development zone to the west is home to the Heilongjiang provincial government complex as well as some of the most expensive and exclusive restaurants in the city. After the city received national level and provincial level funding for transportation and infrastructure development in the area between 1994 and 2001, much of the newly valuable land was leased to high-end restaurants and residential developments, hence the moniker "corruption street." ${ }^{11}$ 
Harbin and Dalian cities, despite initially similar urban landscapes and socio-economic structures, have developed remarkably different urban political economies since 1978. Dalian received open status early during reforms, pushing the local economy toward export orientation and providing access to foreign capital. Reforms to the state sector were undertaken in a climate of competition, both with foreign firms and among domestic firms seeking foreign capital to upgrade and survive. Harbin, like other regional cities without extensive access to foreign capital and investment, attempted to grow through streamlining the public economy and nurturing small-scale entrepreneurship. The municipal government was challenged to execute politically difficult enterprise reforms in a climate of scarcity and fear of social instability. The two cities also represent very different outcomes with regard to the local state's control over territory. Dalian is a case of territorial consolidation; the local state has secured itself as the sole authority over the use, occupation, and allocation of urban territory. Harbin, conversely, is a case of "territorial fragmentation," since various groups outside and inside the local state stake claims to urban spaces and thwart municipal efforts at spatial restructuring. The next two sections detail how a globally-oriented political economy augmented the local state's control over land in Dalian and a political economy of survival eroded that control in Harbin.

\section{TERRITORIAL CONSOLIDATION IN DALIAN}

With its coastal location at the tip of the Liaodong peninsula, Dalian was well positioned in the 1980s to benefit from opening to international trade and investment through the coastal

development policy. ${ }^{22}$ Like cities all over China that would later adopt development zones as the centerpiece of their growth strategies, Dalian's pursued a territorial strategy of spatially segregating the activities of the new economy from those of the old, creating competition both between the globalist and socialist constituencies and also among state firms. Through 
development zoning first and then introducing reforms to the state sector through forced enterprise relocation outside of the urban core, the Dalian municipal state recalibrated the spatial distribution of power in the city and managed urban interests in a way that established the state as arbiter rather than target of political conflict.

\section{Development Zoning}

Dalian's initiation into the "winners' circle" of the reform era began with its designation as one of fourteen coastal open cities in May of 1984, a designation that handed decision-making power regarding foreign capital in the form of foreign-invested enterprises (FIEs) or foreign direct investment (FDI) to the municipal authorities. The city's authorities looked outside the core urban districts for the physical space to anchor new forms of economic activity. Even before Beijing conferred special status upon Dalian, the city’s 1980 master plan (zongti guihua 总体规 划) included preliminary designation of a development zone (kaifaqu 开发区) in what was the Maqiaozi village in then suburban Jinzhou County, a full 35 kilometers from the city center in Zhongshan and Xigang districts (See Figure 3). ${ }^{23}$

(Figure 3 here)

Though the strategy of designating a specific space for foreign-oriented development may strike any present observer of urban China as unexciting, in 1984, directing new investment an hour's driving distance from a traditional urban center was novel. The Dalian Economic Development and Technology Zone (or Dalian Development Area, DDA) was the very first such space in China. ${ }^{24}$ The DDA offered a number of formal benefits to foreign firms to entice them to either invest in local enterprises or relocate to the DDA, including a lower tax rate and no real

estate taxes for the first three years of the investment period. ${ }^{25}$ The strategy of development 
zoning gained greater momentum in the early 1990s after Deng Xiaoping's southern tour. In October 1992, the Dalian Tax Free Zone (baoshui qu 保税区) was established adjacent to the DDA in Jinzhou District, China's “first domestically located, foreign-run (jingnei guanwai 境内

关外) economic area. ${ }^{26}$ Space was also designated for high-technology parks around the DDA and to the southwest of the city center. Figure 4 maps the locations of the 17 smaller “development zones" established between 1992 and 1999 (15 in 1992 alone) throughout the city; only one of the special zones is located within the three core urban districts (Zhongshan, Xigang, and Shahekou).

\section{(Figure 4 here)}

These spatial strategies held certain advantages for the firms that invested in them, advantages economists associate with clustering and agglomeration; access to transport, concentration of skilled labor, opportunities for technology transfer, dense warehousing networks, and so forth. ${ }^{27}$ As spatial zoning for development and clustering have gained currency in international development circles — partially based on the Chinese experience-observers have focused mostly on the benefits to enterprises and less on the political benefits enjoyed by local governments. In Dalian, these special designations allowed the state itself to preside over the spatial distribution of growth and investment and provided a space in which to experiment under conditions of economic and political uncertainty. Municipal publications from the 1980s and 1990s highlight the establishment of the DDA and show pride that the zone was the first of its kind in China. Explanations for the rationale for establishing the zone outside the city, however, make no mention of the economic benefits of clustering, and instead invoke reasons such as avoiding the problems of the urban core and establishing a new place to absorb migrant labor. In 
an explanation of the benefits of Dalian's novel development zoning strategy in a flagship national urban planning magazine, members of the Urban Planning Bureau write,

The new area has an extraordinary number of benefits. Principally, it avoids the downtown area's 'urban heart disease.' Population density [in the urban core] is already declining (though it was already lower than national standard). The migrant populations would threaten the low population density, so it is best to attract them to the new urban area. $^{28}$

Dalian has indeed long been a leading destination for rural-to-urban and inter-urban migration; according to official data, Dalian has by far the largest "floating population" in the Northeast.

The official migration rate between 1980 and 1989 averaged 12 per cent increase per annum. ${ }^{29} \mathrm{~A}$ 1988 Public Security Bureau survey shows more dramatic numbers, estimating a "floating population" (i.e. unofficial migrants without Dalian hukou) of 388,000 people, over 80 per cent of whom resided outside the urban core. ${ }^{30}$ More recent census data on migration confirms that the DDA continues to be the main destination for arrivals from outside the city. Jinzhou and Ganjingzi Districts housed 26 and 30 per cent respectively of Dalian city migrants living outside their place of registration (hukou), and each held 33 per cent— two-thirds in total—of migrants from outside the province. ${ }^{31}$ Popular conceptions of the differences between the "new" and "old" city underscore the importance of the population distribution. Officials in the DDA insisted that the DDA is like an "immigrant city," its population "young, open-minded, and part of China's transformation." 32 People in the Dalian urban core harbor resentment toward the DDA and the people who live and work there, arguing that the city is biased toward the new areas and that Dalian's new wealth only benefits people not originally from Dalian. Rather than blaming the state or city authorities for their bad fortune, the "losers" of reform directed their frustration against another population in the city.

\section{Sequencing of Reforms}


By the early 1990s, the DDA was the liveliest point of the Dalian economy and the locus of market-based productivity. Mary Gallagher has argued that the sequencing of reform and opening at the national level has both bolstered the CCP's grip on power as well as encouraged further economic liberalization. Early FDI liberalization fragmented elements of society and pitted regions against each other in competing for scarce capital flows, recasting the ideological debate over privatization as "one of Chinese industrial survival amid ever-increasing foreign competition. ${ }^{, 33}$ The strategy of development zoning introduced these competitive pressures within the city of Dalian, pitting a moribund state sector in the urban core against a vibrant development zone outside of the city and rendering potential claimants to urban territory and the workers beneath them dependent on the municipal government for survival.

The politically and economically difficult enterprise reforms were undertaken later in the 1990s, as enterprises were forced to relocate from the urban core into new development zones and specially designated industrial zones as part of the city's massive enterprise relocation (banqi 般企) campaign. 1992 became the turning point after which the urban core became a target for redevelopment rather than an area to be avoided in favor of the periphery. The campaign was carried out jointly by the Municipal Bureau of Industry and Commerce (MBIC), Urban Planning and Land Resource Management Bureaus, and the Dalian Municipal Housing Authority, who held authority over approximately 83 per cent of residential housing in the urban core. ${ }^{34}$ With Bo at the head of a campaign to beautify and spatially reconfigure the city, between 1994 and 2001, these institutions relocated 115 enterprises from Zhongshan and Xigang districts alone, freeing over 3 million square meters of land. ${ }^{35}$

Relocation targeted enterprises desperate for capital infusion; municipal authorities would guarantee capital infusions for the enterprises in exchange for turning over downtown land. The 
typical process involved leasing development zone land at a very low cost to an enterprise (an MBIC official in an interview insisted that land was essentially "given away"), and then leasing out the enterprise's former downtown space with a promise that some of the capital acquired would be released to the moved enterprise for facility upgrading and technological investments. ${ }^{36}$ Critically, city officials would also assist with locating foreign joint venture partners for enterprises that agreed to move, enabling the city to simultaneously reclaim downtown land from enterprises and execute management and ownership restructuring. For example, the Bohai Beer Factory, which occupied 30,000 square meters in Zhongshan District, was designated for relocation in 1995. The MBIC negotiated its acquisition by a Hong Kong investment firm, and also turned over half of the land-lease fee to the factory when the Land Management Bureau secured the former area for a Korean Commercial Venture (a large mall). ${ }^{37}$ When Sanyo located production facilities in the DDA in 1996, the DDA assisted with the creation of a large conglomeration firm in which Sanyo was partnered with 16 SOEs relocated from the downtown core. These SOEs were competing with each other to suffer the least number of layoffs. ${ }^{38}$ Municipal authorities, then, concurrently reclaimed factory-occupied land and executed enterprise restructuring.

Securing the acquiescence of factory managers who faced underperforming enterprises and painful downsizing in any case was not especially challenging. The thorny parts of the relocation campaign — and the ones rarely discussed in public celebrations of the remaking of the city — concern the housing compounds that had dominated urban core neighborhoods and the workers who occupied them. ${ }^{39}$ In interviews, officials and urban planners referenced opposition to the relocation work of the 1990s. One urban planner recalled many petitions and attempts at protest in 1994 and 1995, but said that because the local party organizations, residents' 
committees, and work units themselves were not behind the residents, their efforts at collective organization failed. ${ }^{40}$ Another official clearly stated the dilemma facing residents: they stood to lose both their homes and their jobs should they choose to resist relocation. Enterprises often laid off a substantial portion of their work force when they moved and underwent restructuring. Since the work units and factory managers were supportive of relocation plans, residents and workers were actually competing with each other to accept the compensation and relocation arrangements. $^{41}$

The relocation campaign began alongside Bo Xilai's assumption of the city's leadership in 1993 - he had served in various party positions in Jinzhou and the DDA since 1984 - and campaigns to "beautify the city" and transform Dalian into a "commerce and trade, finance, tourism, and informational city."42 Foreshadowing the kind of campaigns Bo would later become infamous for in attempting to transform and re-brand Chongqing, substantial propaganda accompanied efforts and economic and spatial reconfiguration in Dalian. The Urban Planning and Land Resource Management Bureau chief at the time recalls Bo's efforts at softening the term “demolition" (chai 拆): "Bo Xilai himself said that the green of Dalian will emerge from 'chai' and 'ba'(扒) [stripping away]. Don't look down on the word 'chai', because this is really tearing down people's closed hearts and old ideas. ${ }^{" 43}$ The combination of entwining employment prospects with relocation acquiescence, the offer of substantial compensation packages for residents by leasing out land, and ideological campaigns to pressure compliance foreclosed any viable attempts at collectively resisting eviction and relocation.

The Dalian municipal authorities' political economic strategy of global orientation was accompanied by a territorial strategy of expansion and segregation. The creation of the extra- 
urban development zone established competition among state firms for municipal government assistance rather than competition between those firms and the local state for land control. Moreover, the emergent axis of urban politics in Dalian is the reformist, global constituencies in the DDA on the one hand and the waning and descendant former power brokers on the other. The result of both of these types of competition is a strong municipal state that acts as arbiter rather than participant in urban politics and maintains a near monopoly on the use and designation of urban land.

\section{TERRITORIAL FRAGMENTATION IN HARBIN}

City officials in Harbin have encountered significant resistance to their plans for urban renovation and relocation, and plans for urban expansion have fallen prey to mismanagement and intra-local territorial conflict. Harbin's urban landscape is more of a pastiche of power bases than a canvass onto which the local state projects political power and generates wealth. These power bases consist of firm or residential occupants who perceive themselves as de facto-if not de jure-claimants to property rights over urban land that the city has sought to appropriate or reallocate. Unlike its regional counterpart, Harbin had nearly no access to foreign capital early in the reform era and therefore reforms to the public sector were introduced in a climate of resource scarcity. As officials in Harbin weathered the economic reforms of the 1980s and 1990s under these different political economic conditions, the municipal state steadily relinquished control over the urban landscape as a political and economic strategy in its dealings with public sector enterprises, laid-off workers, and the entrepreneurial sector. In this section, I take up each of these arenas in turn.

\section{Public Sector Firms}


While Dalian officials during the 1980s turned outwards, skirting potentially messy programs of reform and contests over urban property with centrally located SOEs, Harbin city officials steadily reinvested, politically and economically, in large state-owned enterprises. City officials did introduce reforms to the state sector, but those reforms were efforts at enterprise conglomeration, consolidation, and upgrading, i.e. revitalizing threatened enterprises by diversifying the economic activities within their purview and further decentralizing authority over their operations. This political economic strategy produced a concomitant territorial strategy of distributing and decentralizing control over urban land.

Harbin's 1985 master plan sought to limit industrial "sprawl" and rationalize layout by concentrating infrastructure investments in extant compounds, mostly located in clusters created early in the Maoist era for heavy enterprises and within the city's six core urban districts. Harbin's four largest industrial compounds were slated to receive investment to "rehabilitate" facilities and housing. ${ }^{44}$ Plans expressly avoided the acquisition of new urban land and confined new industrial construction to existing compounds. Harbin in the 1980s only officially acquired four plots of new land for urban construction, all of which surrounded major industrial compounds within Daoli and Nangang districts. ${ }^{45}$ As early as 1986, the city's highest officials were wrestling with actors from the formal state sector over land control. A 1986 project to build a new transport tunnel through Nangang and Xiangfang Districts interfered with the land operated by a local factory, whose manager asked for over 8 million RMB in compensation. The factory's compliance required the intervention of the mayor himself, who went to the factory manager with the money and personally counted out each bill to reach a "mutual understanding" with the manager. ${ }^{46}$ This strategy of devolving economic and territorial power to enterprises empowered a plurality of urban interests vis-à-vis Harbin's municipal authorities. As enterprises 
in Dalian were becoming dependent on city authorities for funding and survival, Harbin authorities were becoming dependent on enterprise managers for their acquiescence in basic urban plans.

\section{Laid-Off Workers: Housing and Redistribution}

Layoffs and factory closures, particularly in the late 1980s through the late 1990s, created potentially destabilizing sets of "losers" to market reforms, and the use of urban land and control of territory constituted a key resource for redistribution to these groups. ${ }^{47}$ Harbin in the $1980 \mathrm{~s}$ became nationally famous for rehabilitating dilapidated housing compounds that were part of major industrial clusters but not relocating residents.

Urban China experienced a push toward housing construction in the late 1970s and early 1980s with multi-level investment with contributions from central and local governments, investors, enterprises, and individuals. ${ }^{48}$ In Harbin, new funds for housing were dispersed directly to enterprises. ${ }^{49}$ In conjunction with the Municipal Construction Bureau, the enterprises used the money to renovate work unit housing and build new housing within compounds. The flagship projects were the renovation of Harbin's two most famous slums, the " 36 " and " 18 corner" slums, both of which were in the 1950s turned into work unit housing compounds attached to machinery plants under the Harbin MBIC. These plants were some of Harbin's first to undergo privatization and layoffs in the $1990 \mathrm{~s} .{ }^{50}$ One Harbin urban planner in charge of such a project in Nangang District in the late 1980s viewed renovating housing as a form of "insurance" for soon-to-be laid-off workers, since they would get ownership over the apartment that they could then rent at a higher price or feel more willing to take entrepreneurial risk because their

housing was secure. ${ }^{51}$ Investing in housing compounds of threatened enterprises was a territorial 
strategy, resulting from Harbin's political economy of survival, of assuaging potentially contentious "losers" of reforms.

Harbin's general approach to urban territory was one of decentralization, permitting neighborhoods and enterprises to draw up and implement their own local plans (xiangxi guihua 详细规划), albeit with approval of the city’s Urban Planning Bureau. An essay by a prominent urban planner in Harbin reflects on the process of planning in the 1980s:

Harbin has had a difficult time incorporating widely accepted and national standards of good living environments. For example, average living space per person is much lower than the rest of the country, but neighborhoods and surroundings are much more convenient. Harbiners do not want to demolish large parts of the old city to build green space, and new space for commerce and the tertiary industry has developed somewhat

organically in the downtown area without a great deal of demolition and reconstruction. ${ }^{52}$ $\mathrm{Yu}$ concludes that local discretion over the built environment is a condition particular to Harbin and one that has benefitted the distinctive quality of Harbin's urban form. In short, while Dalian was centralizing territorial control, Harbin was distributing that control in exchange for cooperation with reforms to the state-run economic sector.

\section{Emergent Private Industry: Informal Property Rights and the Informal Sector}

As formal sector workers experienced layoffs and wage cuts or anticipated the inevitability, many turned to petty commerce and street-level services as a means of livelihood. The spaces in which these activities emerged in Harbin were those that boasted a rich tradition of private and commercial activity prior to nationalization in 1956. Daoli district, the center of the Russian émigré bourgeoisie in the 1920s, became the epicenter of commercial and service development during the reform era. Daowai district houses the Muslim quarter surrounding the city's largest mosque and was settled very densely by Chinese laborers in the early $20^{\text {th }}$ century. 
Both districts claim a long tradition of vibrant private enterprise, and the commercial impulse was quick to return under conditions of liberalization. ${ }^{53}$

To be sure, the growth (or return) of commercial streets and bourgeois clusters was far from spontaneous. The Harbin MBIC was instrumental in fostering an advantageous environment, institutionally and spatially, for these small commercial endeavors. As early as 1980, the MBIC encouraged experimentation with private business and put forth instructions to ease the registration process for urban private enterprises. By 1981, the city had registered over 12,000 private enterprises, 21 times the number registered at the end of $1978 .{ }^{54}$ Critically, the onus of encouraging, registering, and approving private enterprise rested with lower levels of government. The blossoming of commercial activity — shoe repair, craftsmanship, barber shops, food stalls, teahouses, bakeries and the like—emerged under the purview of street offices (jiedao banshich $u$ 街道办事处) that were extensively integrated with local communities. The municipal branch of the MBIC and its local arms acted as advocates for urban private enterprise, designating spaces for operations and turning a blind eye to these activities when they contradicted other local governmental policies..$^{55}$

Because of conflicts between the Land Management Bureau and lower levels of government seeking to protect the embryonic private sector, the municipal government, against the wishes of the Land Bureau, decreed in November 1989 that all new construction projects, whether industrial or residential, must allot a minimum of seven per cent of space to commercial purposes ${ }^{56}$ Thus emerged a new territorial strategy of clustering the small-scale private sector in designated areas rather than allowing informal appropriations of space. In 1991, commercial streets were officially designated in places where they already informally operating. Central Boulevard boasted 139 independent commercial enterprises by the end of 1991, Fendou Road 
had over 300, and Jingyu Street over 400, most of which were small businesses run by petty entrepreneurs. ${ }^{57}$ By 1995 , the number of these markets had grown considerably. There were 30 more such designated areas, and the city of Harbin boasted three of the nation's fifty largest industrial product markets. ${ }^{58}$ These markets were not only a substantial source of income and economic activity for the city, but also major outlets for reemployment of former public sector workers. By 1998, the city hosted 621 official locations with nearly 78,000 registered businesses, employing over 127,000 people, 60 per cent of whom were laid-off industrial workers. ${ }^{59}$

The privatizations of the late 1990s further diversified control over land in the urban core in two important ways. First, as in many Chinese cities, the sale of public assets, particularly of small and medium SOEs, to private entrepreneurs in the late 1990s entailed rapid commodification of the land occupied by those enterprises. Privatizations were carried out in a climate of particular desperation in Harbin. As a result, many SOE land assets were acquired at much lower rates than they were likely worth. In addition, new owners of former SOE land assets frequently leased land use on secondary markets without ever paying the local government for use rights, either paying sub-market rent to the local government without paying land appreciation tax or simply illegally leasing land for commercial purposes. ${ }^{60}$ The second way in which these privatizations contributed to the erosion of state land control concerns the simultaneous implementation of housing privatization and SOE restructuring. In part because of the enterprise reforms in the late 1990s but also in part to stimulate an ailing economy following the Asian Financial Crisis, housing previously owned and managed by work units was privatized all over China in 1998. In Harbin, the implementation of housing privatization during a politically difficult climate of layoffs and strikes, in combination with the fiscal difficulties of SOEs and the local state, led to the sale of public housing at high losses for the state, entrenching 
workers in their longtime homes and neighborhoods and denying local government prime urban real estate for years to come. ${ }^{61}$ For example, municipal officials not only sold off SOE housing in Xiangfang and Pingfang districts at highly subsidized rates, but also invested further funds in upgrading those housing compounds. ${ }^{62}$ These were the exact industrial compounds to experience substantial worker unrest, particularly joint strikes and marches among a number of small and medium SOEs, in January $1997 .{ }^{63}$

By the late 1990s, land control had become one of the most politically salient issues in Harbin, taking a close second place to labor issues even during the most intense strike wave of the decade in $1997 .{ }^{64}$ Harbin's economic policies generated territorial strategies that emboldened quasi-state actors in enterprises and encouraged new claimants to downtown land in the form of a new class of urban entrepreneurs. In addition to struggles with firms and residents, various arms of the municipal administration dealt differently with their constituencies in struggles over land control, precluding the municipal state from exercising the kind of unified control over territory that its counterpart in Dalian did. Once relinquished, territorial control becomes difficult to re-assert; in an institutional climate in which property rights over land are highly ambiguous, informal control constitutes a powerful claim to ownership. ${ }^{65}$ Moreover, entrepreneurs and residents who occupy the same space for long periods of time find it easier to articulate a collective interest over their continued right to that space. ${ }^{66}$ In this sense, informal control over territory becomes self-perpetuating: once a municipal state becomes mired in territorial fragmentation, the path becomes difficult to reverse.

\section{CONCLUSION}


Urban landscapes in China are canvases onto which governments project political power, and land is the primary commodity through which urban governments generate revenue. Ambiguity in national institutions governing property rights, however, leaves substantial maneuver space at the local level, producing variation in local state control over land. ${ }^{67}$ The level of territorial control a local state exercises, therefore, offers insight into local state capacity and state-market relations. Based on a comparison of two cities that faced similar initial constraints yet, because of preferential policies and the sequencing of reforms, adopted different courses of managing urban territory, this article has established a framework for a comparative political economy of land control. Patterns of land politics in Dalian and Harbin suggest that early access to preferential policies empowered the local state vis-à-vis groups in society, while the lack of access forced local governments to grant concessions to urban constituencies. It is in the wealthier, more globalized city in which territorial and political power are more concentrated in the hands of the local state.

This finding is surprising in light of expectations for the relative power of states and markets in China. At the beginning of the reform era as much as now, many have assumed that reforms would relax state control over urban life and urban landscapes, as if the freedom of the market would supplant state management of Chinese cities. With regard to urban land politics, these assumptions have taken the form of arguments that new features of urban landscapes in Chinese cities are somehow "organic" results of marketization, absent of the state engineering that marked the pre-reform era, or that greater degrees of market reforms would correlate with freer urban land markets and greater pluralities of landed interests. ${ }^{68}$ But precisely by linking varying political economies of reform with the territorial strategies they produced, this comparison of 
two regional cities demonstrates how foreign opening and economic reform amplified local state power, while reforms under scarcity generated power-sharing concessions.

While there are limits to the ability to generalize from two cases, this comparison of cities in the Northeast suggests two additional, preliminary conclusions for land politics in China. The fact of ambiguity over land rights in rural China has received a great deal of scholarly attention, but less so the same fact inside China's cities, at least from a political economy perspective. ${ }^{69}$ This lacuna is regrettable considering the clear importance of real estate investment, housing provision, and demolition and relocation in urban China. One preliminary conclusion from this comparison is that urban China is likely home to a multitude of informal property rights regimes that have developed concurrently with reform and opening policies over the last three decades. Instead of being a function of changes in central policy toward urban land - or perhaps more precisely because of the ambiguity of these policies - property rights claims at local levels are possibly endogenous, i.e. they emerge as a result of de facto practices like informal investments or agreements over land control rather than as a result of any process of de jure institutional change. ${ }^{70}$ If so, future research on land politics may benefit more from detailed, empirical comparisons of cities in addition to tracking the evolution of central policy and the politics of rural land conversion.

Yet, that different informal property rights regimes have emerged endogenously in different cities should not prevent us from attempting to theorize what kinds of regimes emerge under which political economic conditions. I have emphasized here the causal importance not of socialist legacies or central policy in driving different political economies of land control, but instead the role of changes to the post-Mao urban hierarchy and the sequencing of reform and opening at the local level. Such a finding suggests that urban China will not likely converge on 
any single model of land politics or urban property rights in the near future, but rather be home to multiple different models that tend to be self-reinforcing. This continued divergence in land control regimes will complicate the ability of the central government in Beijing to achieve uniform results in a number of recent policy goals, such as the provision of subsidized housing, reining in the conversion of agricultural land, and cooling housing and real estate markets.

Table 1: Basic Demographic and Economic Indicators, Harbin and Dalian, 2008

\begin{tabular}{|c|c|c|c|}
\hline & unit & Harbin & Dalian \\
\hline Land Area & $\mathrm{km}^{2}$ & 53068 & 12573.85 \\
\hline Population & persons & 9898600 & 5833745 \\
\hline $\begin{array}{l}\text { GRP } \\
\text { Primary } \\
\text { Secondary } \\
\text { Industry } \\
\text { Tertiary }\end{array}$ & billions RMB & $\begin{array}{c}286.82 \\
39.02(13.6 \%) \\
107.7(51.7 \%) \\
80.98(28.2 \%) \\
140.04(48.8 \%)\end{array}$ & $\begin{array}{l}385.8 \\
28.91(7.5 \%) \\
199.3(51.7 \%) \\
177.85(46.1 \%) \\
157.5(40.8 \%)\end{array}$ \\
\hline Per Capita Income & RMB & 29012 & 63198 \\
\hline Unemployment* & per cent & 3.2 & 2 \\
\hline $\begin{array}{l}\text { Employment } \\
\text { Selected data by ownership }{ }^{* *} \\
\text { SOEs } \\
\text { Urban Collectives } \\
\text { Hong Kong, Taiwan, Macao } \\
\text { invested } \\
\text { Foreign-owned } \\
\text { Private } \\
\text { Self-employed }\end{array}$ & $\begin{array}{l}\text { million persons } \\
\text { / } \\
\text { share of total } \\
\text { reported } \\
\text { workforce }\end{array}$ & $\begin{array}{l}2.38 \\
.834(35 \%) \\
.202(8.5 \%) \\
.018(0.7 \%) \\
\\
.023(1 \%) \\
.383(16 \%) \\
.214(8.9 \%)\end{array}$ & $\begin{array}{l}.9501 \\
.2678(28 \%) \\
.0232(2.4 \%) \\
.0413(4.3 \%) \\
.2441(25.7 \%) \\
- \\
-\end{array}$ \\
\hline $\begin{array}{l}\text { Fixed Asset Investment } \\
\text { Residential Buildings } \\
\text { Real Estate }\end{array}$ & billions RMB & $\begin{array}{l}131.43 \\
13.363 \\
21.58 \\
\end{array}$ & $\begin{array}{l}251.38 \\
37.813 \\
49.582 \\
\end{array}$ \\
\hline $\begin{array}{r}\text { Revenue } \\
\text { Local }\end{array}$ & billions RMB & $\begin{array}{l}28.5 \\
16.4\end{array}$ & $\begin{array}{l}91.6 \\
33.907\end{array}$ \\
\hline Expenditure & billions RMB & 30.13 & 41 \\
\hline $\begin{array}{l}\text { GVIO } \\
\text { Selected data by ownership*** }\end{array}$ & $\begin{array}{l}\text { billions RMB / } \\
\text { share of total }\end{array}$ & 244.1 & 582.7 \\
\hline
\end{tabular}




\begin{tabular}{|c|c|c|c|}
\hline $\begin{array}{l}\text { Domestic } \\
\text { SOEs } \\
\text { Collective } \\
\text { Private } \\
\text { Hong Kong, Taiwan, Macao } \\
\text { Invested or owned } \\
\text { Foreign-invested or owned }\end{array}$ & GVIO & $\begin{array}{ll}140.3 & (57.5 \%) \\
33.5 & (13.7 \%) \\
24.1 & (9.9 \%) \\
18.3 & (7.5 \%) \\
23.3 & (9.5 \%) \\
& \\
37.12 & (15.2 \%)\end{array}$ & $\begin{array}{l}335.6(57.6 \%) \\
31.0 \quad(5.3 \%) \\
3.13 \quad(0.5 \%) \\
120.6(20.7 \%) \\
16.8(2.9 \%) \\
210.3(36 \%)\end{array}$ \\
\hline FDI & \begin{tabular}{|l|} 
millions USD \\
\end{tabular} & 543.09 & 5007 \\
\hline
\end{tabular}

All data from year end 2008 and for entire municipalities, i.e. including subsidiary counties and cities. I display 2008 data in order to match the timing of the qualitative descriptions of the cities. All data, unless otherwise indicated, from Harbin Statistical Yearbook 2009 (Haerbin 2009 tongji nianjian) and Dalian Statistical Yearbook 2009 (Dalian 2009 tongji nianjian). * From Zhongguo laodong tongji nianjian 2008 (China Labor Statistical Yearbook 2008): 153. Accessed through China Academic Journals. **Because of incongruous reporting of data across cities, it is not possible to directly compare the labor force break down by ownership in 2008. These data are selected shares by ownership, and therefore do not add to $100 \%$. $* * *$ These data are selected shares by ownership, and therefore do not add to $100 \%$.

Figure 1: China, the Northeastern Provinces, and the Research Sites 


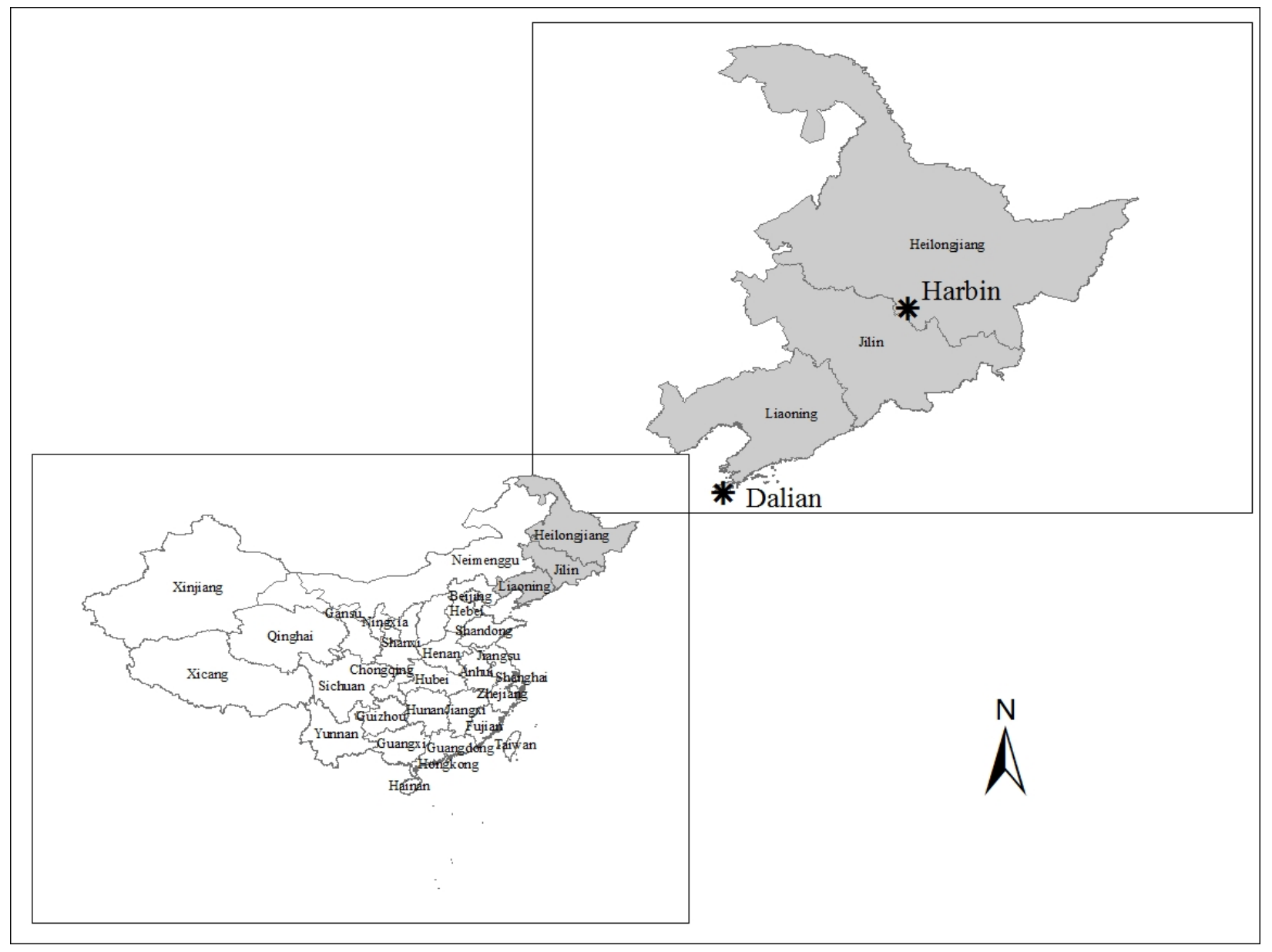

Figure 2: Harbin City and Urban Core Districts, $2000^{71}$ 


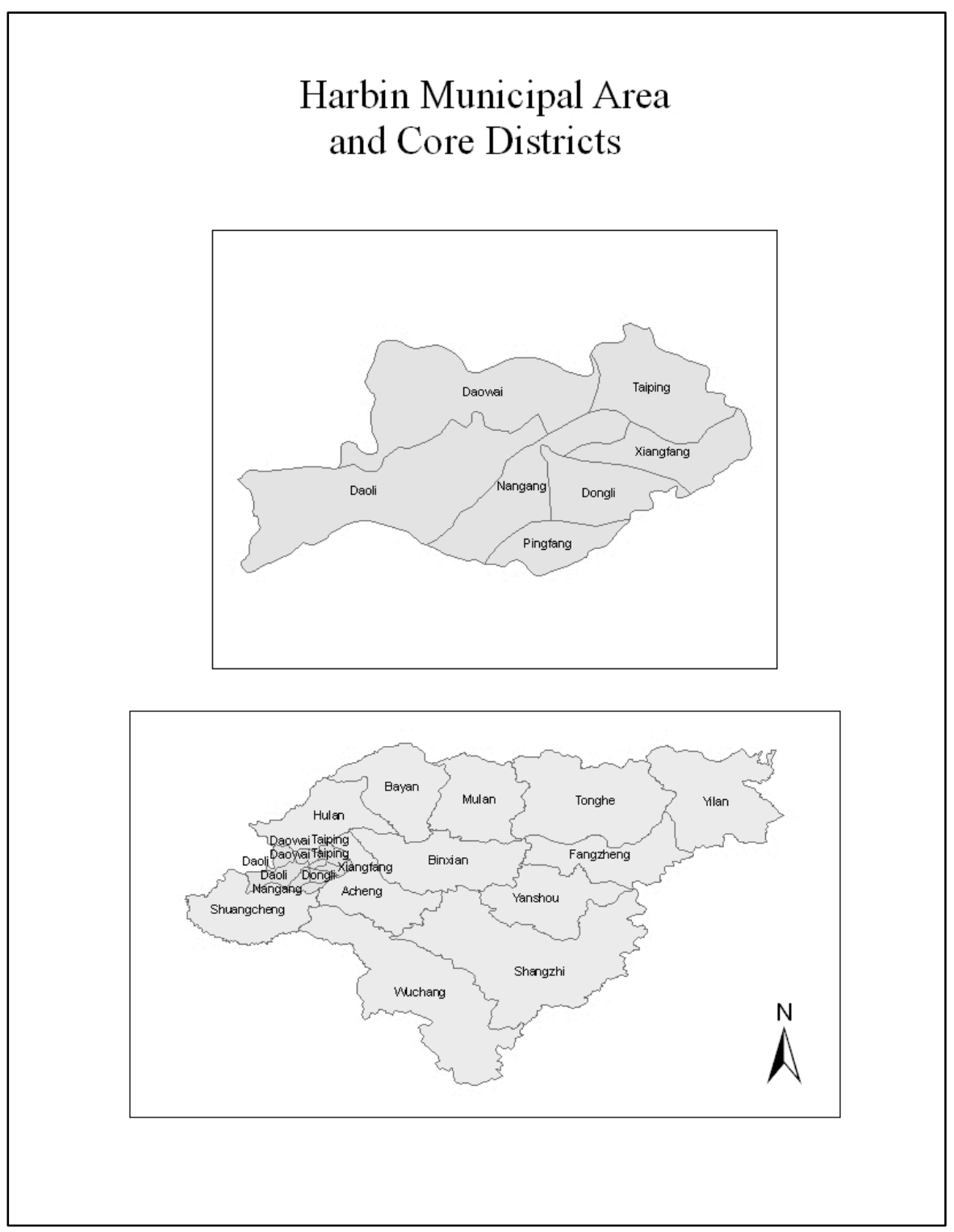

Figure 3: Dalian's Urban Core and the Development Area, 2008 


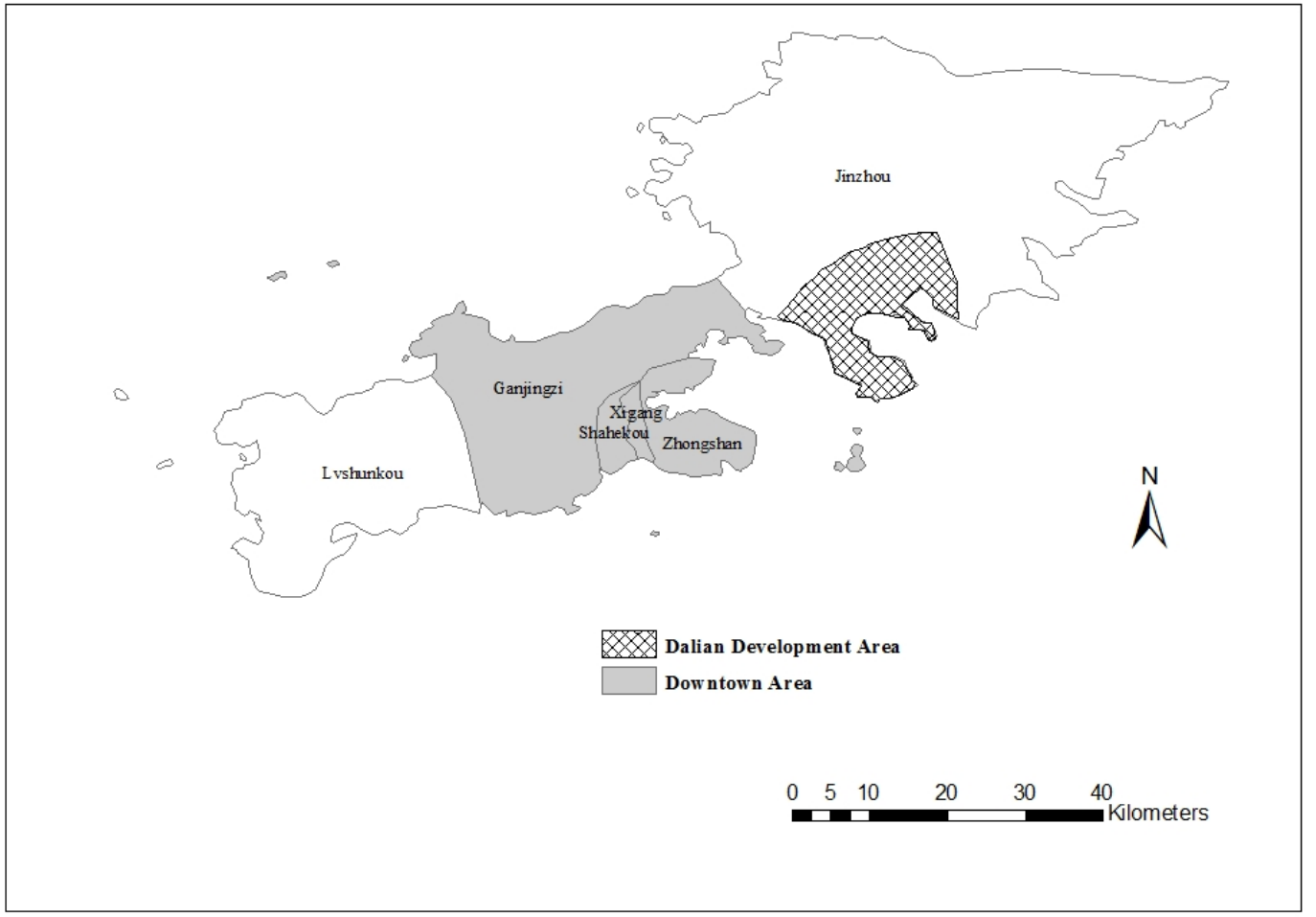

Figure 4: Dalian City Small Development Zones 


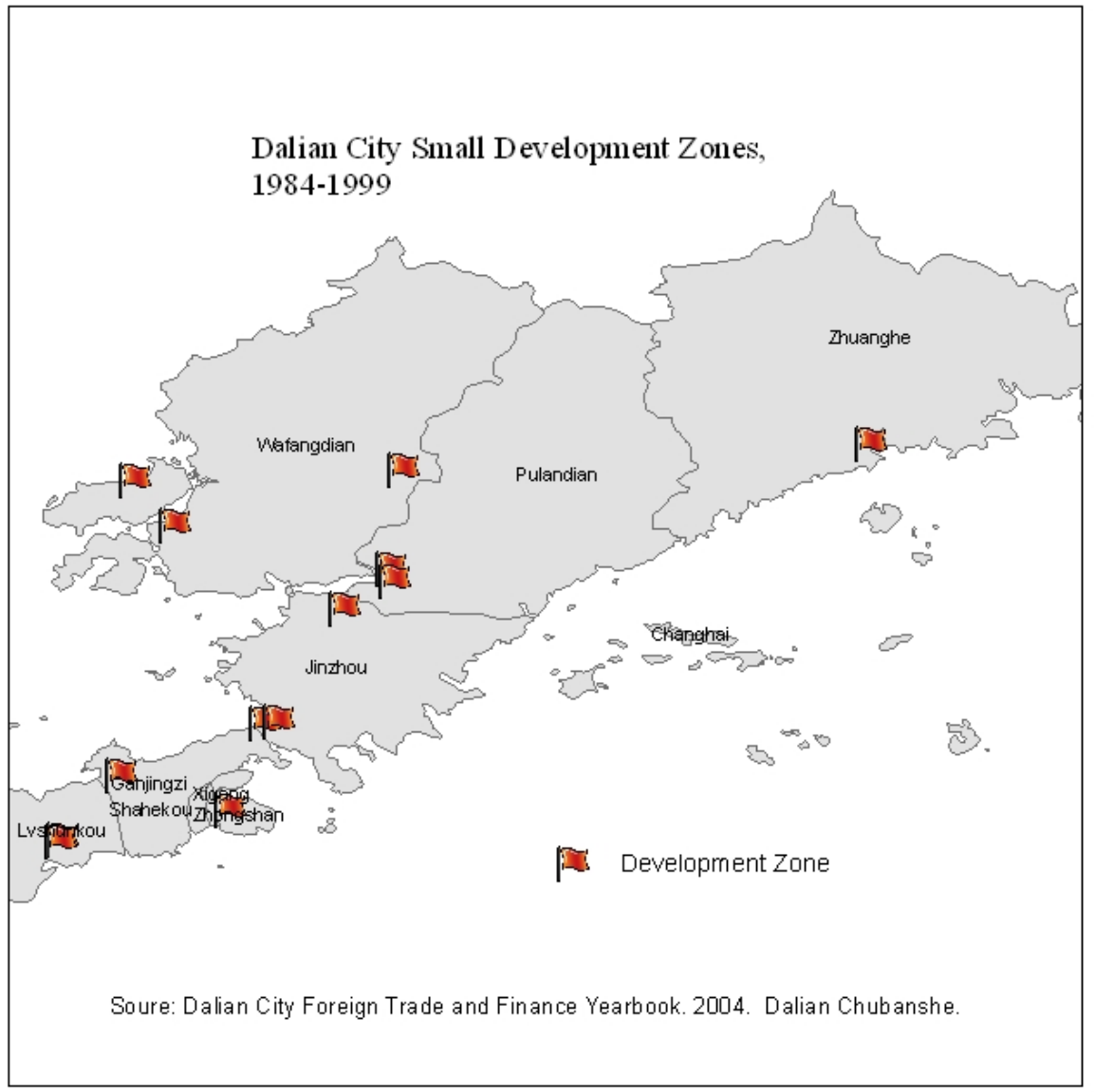




\section{Bibliography}

Besley, Timothy. 1995. "Property rights and investment incentives: Theory and evidence from Ghana.” Journal of Political Economy. 103 (5), 903-937.

Bo Xilai. 2003. "Ruhe jingying chengshi zhefen guoyou zichan," ("How to operate a city as state asset), in Liu Changde, ed. Chengshi jiaoxiang: Dalian shi linian yu shixian (Symphony of a City: The Idea and Practice of Dalian City). Beijing: Qinghua University Press.

Cai Xuefu, Wang Fang, and Deng Jiazhan. 1992. "Chu yijiang Dalian Shi Jiangshe Chengwei xiandaihua guojixing chengshi de fazhan moshi" ("Considering building Dalian city's form to become a modern, international city”). Chengshi Guihua. (Urban Planning). April, 52- 55.

Cai Yongshun and Fayong Shi. 2006. "Disaggregating the state: Networks and collective action in Shanghai," China Quarterly. 186, 314-332.

Chovanec, Patrick. 2011. "China's real estate bubble may have just popped." Foreign Affairs. (18 December)

Chung, Jae Ho. 1999. "Preferential policies, municipal leadership, and development strategies: A comparative analysis of Qingdao and Dalian," in Jae Ho Chung, ed. Cities in China: Recipes for Economic Development in the Reform Era. New York: Routledge.

Jae Ho Chung. 2004. 'China's 'City System' in Flux: Explaining Post-Mao Administrative Changes.” China Quarterly. 180, 945-964.

Jae Ho Chung, Hongyi Lai, and Jang-Hwan Joo. 2009. "Assessing the 'Revive the Northeast' (zhenxing dongbei) programme: Origins, policies and implementation." China Quarterly. 197, 107-125.

Duckett, Jane. 1998. The Entrepreneurial State: Real Estate and Commerce Departments in Reform Era Tianjian. New York and London: Routledge.

Fan, C. Cindy. 1997. "Uneven development and beyond: Regional development theory in postMao China." International Journal of Urban and Regional Research. 21 (4), 620-639.

French, Howard. 2007. "In China, fight over development creates a star," New York Times. 23 March.

Gallagher, Mary. 2005. Contagious Capitalism: Globalization and the Politics of Labor in China. Princeton: Princeton University Press.

Gaubatz, Piper Rae. 1995. "Urban transformation in post-Mao China: Impacts of the reform era on China's urban form," in Deborah S. Davis, Richard Kraus, Barry Naughton, and Elizabeth J. Perry, eds. Urban Spaces in Contemporary China: The Potential for Autonomy and Community in post-Mao China. Cambridge: Cambridge University Press.

Glaeser, Edward. 2008. Cities, Agglomeration, and Spatial Equilibrium. New York: Oxford University Press. 
Gu Wanming. 1987. "Yizhi chengshi bing: Haerbin chengshi gaizao lueji” ("Treating urban illness: Harbin city's renovation strategy”). Liaowang Magazine. 44 (3), 21-22

Hamer, Andrew. 1990. "Four hypothesis concerning urbanization," in R. Yin-wang Kwok, William L. Parish, Anthony Gar-on Yeh, Xu Xueqing, eds. Chinese Urban Reform: What Model Now? Armonk, NY: ME Sharpe.

Harbin Urban Planning Bureau, ed. Selected Works of Harbin City Planning in the Beginning of the New Century. (Haerbin xin shiji chu chengshi guihua zuopin xuanji). Harbin: Harbin Chubanshe (2002)

Herbold, Robert. 2011. "China vs. America: Which is the developing country?" Wall Street Journal (9 July).

Hess, Christian. 2011. "From colonial port to socialist metropolis: War, imperialism and the making of "New Dalian." Urban History 38(3), 373-390.

Ho, Peter. 2011. "Who Owns China's Land? Policies, Property Rights, and Deliberate Institutional Ambiguity.” China Quarterly. (166), 394-421.

Ho, Samuel PS and George CS Lin. 2003. "Emerging Land Markets in Rural and Urban China: Policies and Practices." China Quarterly. (175), 681-707.

Hoffman, Lisa. 2006. "Urban transformation and professionalization: Translocality and rationalities of enterprise in post-Mao China," in Oakes, Tim and Louisa Schein, eds. Translocal China. New York: Routledge.

Hsing, You-Tien. 2006. "Land and territorial politics in urban China.” China Quarterly. (187): 575-591.

Hsing, You-Tien, 2010. The Great Urban Transformation: Politics of Land and Property in China. Oxford: Oxford University Press.

Hu Ying. 2006. "Chengshihua jincheng zhong shidi nongmin zuizhong shenghuo anzhi wenti de kaolü." ("Reflections on the problem of allocating support to peasants made landless during urbanization"). Nongye jingji. (Agricultural Economics). (June), 56-57.

Hurst, William. 2009. The Chinese Worker After Socialism. New York: Cambridge University Press.

Lee, Ching Kwan. 2007. Against the Law: Labor Protests in China's Rustbelt and Sunbelt. Berkeley: University of California Press.

Li Jingyu. 2004. "Dongbei diqu chengzhang wei zhongguo disi da jingji zhengzhanji de zhanlue sikao." "'Strategic thinking towards making the Northeast the fourth economic engine for China"). Jingji yanjiu cankao. (Reference Materials for Economic Research). (6), 31-32.

Lin, George CS. 2009. Developing China: Land, Politics and Social Conditions. London: Routledge. 
Liu Changde, ed. 2001. Dalian chengshi gui hua yi bai nian (Dalian City Planning 100 Years, 1899-1999. Dalian Naval Affairs University Publishing House.

Liu Changde, ed. 2004. Chengshi jiaoxiang: Dalian shi linian yu shixian (Symphony of a City: The Idea and Practice of Dalian City). Beijing: Qinghua University Press.

Logan, John, Yiping Fang, and Zhanxin Zhang. 2011. "The Winners in China's Housing Reform," in Joyce Yanyun Man, ed. China's Housing Reform and Outcomes. Cambridge, MA: Lincoln Land Institute.

McKinsey Global Institute. 2008. "Preparing for China's urban billion." http://www.mckinsey.com/mgi/publications/china urban_billion/. Accessed 21 August 2010.

Nathan, Andrew. 2008. "Medals and rights: What the Olympics reveal, and conceal, about China." The New Republic, 9 July.

Segal, Adam. 2003. Digital Dragon: High-Technology Enterprises in China. Ithaca, NY: Cornell University Press.

Qin Shao. 2010. "Waving the red flag: Cultural memory and grass-roots protest in housing disputes in China." Modern Chinese Literature and Culture. 22(1), 197-232

Yang Liu. 2005. "Jingti tudi jiufen baolihua miaotou" ("Guarding against a trend of land dispute violence"). Liaowang. (29), 18 July.

Yu Binyang, ed. 2002. 21 shiji Ha'erbin chengshi guihua duice yanjiu. (2 $1^{\text {st }}$ Century Harbin City Planning Measures Research). Harbin: Harbin Chubanshe, 2002.

Yue Zhang. 2008. "Steering toward growth: Symbolic urban preservation in Beijing, 19902005," Town Planning Review. 79 (2-3), 187-208

Zhao Dingxin. 2001. The Power of Tiananmen: State-Society Relations and the 1989 Student Movement. Chicago: University of Chicago Press.

Zhu Yongquan. 1996. Haerbin tudi guihua yu guanli. (Harbin Land Planning and Management). Shenyang: Liaoning University Press.

\footnotetext{
${ }^{1}$ I gratefully acknowledge funding support from the Institute for International Education, the Chinese Ministry of Education, and the Harvard Academic Real Estate Initiative. In addition, I wish to thank Elizabeth Perry, Alan Altshuler, Timothy Colton, Kristen Looney, Jonas Nahm, Chris Bramall, and Andy Harris for comments on versions of the paper.

${ }^{2}$ For these perspectives, see Herbold 2011; Nathan 2008, 41.

${ }^{3}$ This characterization from Hsing 2010.

${ }^{4}$ Sixty percent of peasants who file complaints (shangfang) with higher-level governments do so over lost land, thirty percent of which is lost due to state acquisition (zhengyong). See Hu 2006. Chinese magazines frequently report beatings, assaults, incinerations, and mass brawls between peasants and local leaders over land disputes. Yang Liu 2005.
} 
5 On Beijing, see Zhang 2008; on Shanghai, see Qin 2010. The phenomenon of "nail houses" (dingzihu), residences whose occupants refuse to relocate that stand in the middle of vast construction projects, is endemic in almost every Chinese city. See French 2007.

${ }^{6}$ Chovanec 2011.

${ }^{7}$ Hsing 2006, 577.

${ }^{8}$ On regional variation in political economy in China, see Lin 2009; Hurst 2009; Fan. 1997.

${ }^{9}$ Ho, Samuel. and Lin 2003; Ho, Peter. 2001.

${ }^{10}$ See Hurst 2009, 36.

${ }^{11}$ See Chung 2004.

${ }^{12}$ Hess 2011; Chung, Lai and Joo 2009; Li 2004.

${ }^{13}$ Lee $2007,70$.

${ }^{14}$ Hoffman 2006, 110.

${ }^{15}$ McKinsey Global Institute 2008, 226.

${ }^{16}$ Dalian shi aiguo weisheng yundong zhi, 1988-1998. (Dalian City Patriotic Sanitation Movement Annals). Dalian (1999) 2-3. Dalian shi huanjing baohu zhi (Dalian City

Environmental Protection Annals). Dalian (2003): 1-2.

${ }^{17}$ Bo 2003, 9 .

${ }^{18}$ Haerbin Ribao (Harbin Daily). (31 October 2007) reports that rents along Nanerdaojie, a 100 year old hutong, are on par with those of newly constructed residential neighborhoods in Daoli. ${ }^{19}$ Harbin City Songbei New Area Master Plan Draft, 2010-2020. (Haerbin Shi Songbei xinqu zongti guihua fang'an, 2010-2020). 2002. Harbin Urban Planning Bureau and Harbin Urban Planning and Design Research Institute. In Harbin Urban Planning Bureau, ed. Selected Works of Harbin City Planning in the Beginning of the New Century. (Haerbin xin shiji chu chengshi guihua zuopin xuanji). Harbin: Harbin Chubanshe (2002): 144-145.

${ }^{20}$ A planner with the Harbin City Planning Office estimated that only $50 \%$ of the housing units had sold, and far fewer than that were occupied. I suggested that I go at night and count the lights, and this planner and an intern exclaimed that I should not because the area is unsafe at night. The perception that the city's newest area and the home of the city government is unsafe at night underscores the failure of the expansion plan. 23 September 2007.

${ }^{21}$ See Harbin City Urban Planning Research Institute, Harbin City Development Zone New Zone Master Plan Report (Haerbin shi kaifaqu xinqu zongti guihua zhuanti baogao) 2004. It would be in accurate to characterize the zone as a complete failure, but officials in the city are displeased with the lack of productive investment in the area. The report laments that despite a focus on resettling the city's financial industries in the area, $80 \%$ of the investment in the financial industry still flows to enterprises in Nangang and Daoli districts, 80.

${ }^{22}$ On this, see Fan 1997, 623.

${ }^{23}$ On the 1980 city plan, see Liu Chengde, ed. 2001, 112.

${ }^{24}$ Dalian's Economic and Technology Development Zone was the first open zone within the jurisdiction of a city. The Special Economic Zones (SEZs) - Shenzhen, Zhuhai, Shantou, and Xiamen-were designated as entirely open cities in 1979.

${ }^{25}$ See Chung 1999; Dalian shi zhi: waijing waimao zhi (Dalian City Foreign Trade and Opening Gazetteer). (Dalian: Dalian Publishing Company, 2004): 518-539.

${ }^{26}$ Dalian shi zhi: Chengshi jianshi zhi (Dalian City Construction Gazetteer.) (Dalian: Dalian Publishing Company, 2004): 548. 
27 See Glaeser 208. For the Chinese case, see Segal 2003.

${ }^{28}$ Cai ,Wang, and Deng 1992, 52- 55.

${ }^{29}$ Liu Changde, ed. 2001: 154.

${ }^{30}$ Liu Changde, 2001.

${ }^{31}$ China 2000 Census Data. County level census 2000. China Data Online. Accessed June 2012. Calculations based on only data for urban districts in Dalian, i.e. excluding counties and subsidiary cities. These data include only "floaters," i.e. non-hukou migrants. The data for migrants with hukou is similarly illustrative of the direction of migration into Dalian. In 2008, the core urban districts accounted for $67 \%$ of the city's net growth (i.e. immigrants minus emigrants), and Jinzhou District alone accounts for 32 percent of the total net change. Dalian shi tongji nianjian 2009. (Dalian City Statistical Yearbook 2009): 646.

${ }^{32}$ Group interview with DDA management committee members. March 2008.

${ }^{33}$ Gallagher 2005, 18.

${ }^{34}$ Interview with former MBIC official (served 1991-1997). January 2008. Housing data from 1985-1986 National Housing Survey. Cited in Dalian Nianjian, 1986. (Dalian 1986 Yearbook): 62.

${ }^{35}$ Exhibit in Dalian Modern Museum (Dalian Xiandai Bowuguan), visited February 2008. This was nearly half of the large and medium enterprises in the city at the time. Dalian Nianjian, 1994. (Dalian 1994 Yearbook).

${ }^{36}$ Interview with former MBIC official (served 1991-1997). January 2008.

${ }^{37}$ Example cited in Liu Changde, ed. 2004, 16.

${ }^{38}$ Group interview with DDA management committee members. March 2008.

${ }^{39}$ Credible estimates of the numbers of residents relocated in the 1990 s are scarce. The December 1995 "Dalian City Residential Neighborhood Work Law" set an agenda of creating 95 small residential districts (formally part of the "Hong Kong of the North" campaign) and 175 more in 1996, relocating over 280,000 people in less than a year, which indicates some idea of scale. Dalian shi aiguo weisheng yundongzhi, 1988-1998. (Dalian Patriotic Cleanliness Campaign, 1988-1998) (Dalian: Dalian Patriotic Cleanliness Campaign Committee, 2001).

${ }^{40}$ Interview with Urban Designer at Dalian Urban Planning Bureau, October 2007, Dalian. On the importance of these networks, see Cai and Shi 2006.

${ }^{41}$ Interview with former MBIC official (served 1991-1997). January 2008, Dalian.

42 “Jianfu kaituo de shiming yu zeren: fang Dalian shi guihua he guotuziyuanju Wang Zhenggang juzhang" ("Taking on the Opening Mission and Responsibility: An Interview with Dalian Urban Planning and Land Resource Management Bureau chief Wang Zhenggang”). In Liu Changde, ed. 2004, 16.

${ }^{43}$ In Chinese, "keyi chaidiao renmin fengbi de xinli he jiu de gainian." In Liu Changde, ed. 2004, 15-16.

${ }^{44}$ Harbin City 1985 Master Plan. Harbin City Management Department, 1984. (Archives of the Urban Planning Society of Municipal Harbin): 6-7. The industrial clusters in Pingfang, Sankeshu, Haxi, and Dongli were each one of the national 156 "key point" projects for industrial construction in the first Five Year Plan. Harbin Shi: Chengshi guihua, tudi, shizheng gongyong jianshe zhi (Harbin City Construction Gazetteer). (Harbin: Heilongjiang Renmin Chubanshe, 1998). 
${ }^{45}$ Harbin City 1985 Master Plan. Harbin City Management Department, 1984. (Archives of the Urban Planning Society of Municipal Harbin): 8; Yu Binyang, ed. 2002, 11.

${ }^{46} \mathrm{Gu} 1987,21-22$.

${ }^{47}$ Lay-offs in Northeastern SOEs began earlier than the late 1990s, though these lay-offs were often informal and discussed as "breaks" from work rather than unemployment. See Hurst 2009, 43-44.

${ }^{48}$ Xiandai Zhongguo de jianshe (Contemporary China's Construction). (Beijing: Academy of Social Sciences Press, 1990): 108-110.

${ }^{49}$ Xinhua 28 November 1980 (FBIS); Harbin Party History Materials, Part 3. (Ha'erbin dangshi ziliao) Harbin Municipal Archives, D235.351/01-3. The Municipal Party Committee actually devolved control over housing assignments to worker congresses (gonghui) after unrest over unfair housing assignments.

${ }^{50}$ Interview with Vice Director of Harbin Society of Urban Planners, October 2007.

${ }^{51}$ Interview with Senior Urban Planners, retired. November 2007.

${ }^{52} \mathrm{Yu}$ Binyang, "Create the Concept of Modern Urban Planning and Act as the 'Dragon Head' of City Management," in Yu, ed. 2002, 76. This essay was selected by the Municipal government as the third most outstanding essay on Harbin published in 2002 - a sign that Yu's views are reflecting those of the authorities.

${ }^{53}$ Daowai before 1949 was home to 4950 self-owned stores and businesses - $63 \%$ of such businesses citywide. Haerbin shi Daowai qu shehui jingji fazhan tongji zonghe nianjian, 19781987. (Daowai District Social and Economic Development Comprehensive Statistical Yearbook, 1978-1987). Harbin, 1988: 3.

${ }^{54}$ Heilongjiang sheng minying qiye jingji nianjian. (Heilongjiang Province Private Enterprise Economic Yearbook.). (Harbin: Heilongjiang Renmin Chubanshe, 2004): 102.

55 Interviews with members of Daowai District Commerce Association, March 2008. Business owners throughout Jingyu market accredited the MBIC, chiefly its Daowai district organ, for their survival during the hard times of the 1990s.

56،"Harbin City Measures on Construction Management of Commercial Space" (Haerbin shi shangye wangdian jianshe guanli banfa). Haerbin Nianjian, 1990. (Harbin Yearbook, 1990): 271, 597. This section relies heavily on an interview with two senior Urban Planners, now retired. November 2007.

${ }^{57}$ Haerbin Nianjian, 1992. (Harbin Yearbook, 1992): 223.

${ }^{58}$ Haerbin Nianjian, 1995. (Harbin Yearbook, 1995): 65. These markets were the physical spaces in which enterprises that produced over planned quotas could sell their wares at market for retained profits and enterprises on the demand side were permitted to source their own materials at prices determined by market exchange.

${ }^{59}$ Haerbin Nianjian, 1999. (Harbin Yearbook, 1999): 70.

${ }^{60}$ Interview with multiple Land Resource Bureau officials, November 2007. Note that this "loss of land resources" through ownership changes was occurring in Harbin as early as 1993 according to Zhu Yongquan, the director of the Harbin Land Management Bureau in the late 1980s through mid-1990s, Zhu 1996. This kind of illegal land use was pervasive all over China. Ho and Lin 2003, 696-98.

${ }^{61}$ This is not unique to Harbin, but likely occurred in many cities facing fiscal difficulties in the late 1990s. See Logan, Fang, and Zhang 2011. 
${ }^{62}$ Urban Planning Bureau of Harbin Municipality and Urban Planning and Design Research Institute, 2004. Master Plan of Harbin, 2004-2020: Manual. (Haerbin Chengshi Guihua Zongti Guihua (2004-2020) Shuoming Shu): Chapter 8.

${ }^{63}$ Harbin Yearbook, 1998. [Haerbin Nianjian, 1998]: 124.

${ }^{64}$ According to letters and visits (xinfang shangfang) data for 1997, issues of insurance, pension, and wages for laid-off or retired workers accounted for $25 \%$ of collective visits or letters (that is, group visits and petitions), and city construction, relocation, and planning accounted for another 20\%. Haerbin Nianjian, 1998. (Harbin Yearbook, 1998): 83.

${ }^{65}$ Besley 1995.

${ }^{66}$ Cai and Shi 2006; on the role of ecology in collective action in China, see Zhao 2001.

${ }^{67}$ Ho, P. 2001.

${ }^{68}$ E.g., Hamer 1990; Gaubatz 1995.

${ }^{69}$ Exceptions include Hsing 2006; Hsing 2010; Duckett 1998.

${ }^{70}$ See Besley 1995.

${ }^{71}$ In 2004, Taiping District merged with its surrounding districts, and Hulan County, north of the Songhua River, became Songbei and Hulan Districts. 